\title{
A CSALÁDORVOSKÉPZÉS ÉS -TOVÁBBKÉPZÉS, TUDÁSMEGOSZTÁS ASPEKTUSBÓL
}

\section{EXAMINATION OF GENERAL PRACTITIONERS' EDUCATION AND TRAINING FROM KNOWLEDGE SHARING ASPECT}

\author{
Schmidt Péter ${ }^{1 *}$, Konczosné Szombathelyi Márta ${ }^{2}$, Laczka Éva ${ }^{3 *}$, Tokaji Károlyné4, Rurik Imre \\ ${ }^{1}$ CSc, habilitált egyetemi magántanár, az orvostudomány kandidátusa, egyetemi oktató, családorvos \\ praxismed@externet.hu \\ ${ }^{2} \mathrm{PhD}$, habilitált egyetemi tanár, Széchenyi István Egyetem \\ ${ }^{3} \mathrm{PhD}$, c. egyetemi tanár, a Magyar Statisztikai Társaság elnöke \\ ${ }^{4}$ szakmai főtanácsadó, vezető-fótanácsos, Központi Statisztikai Hivatal \\ ${ }^{5}$ az MTA doktora, PhD, DSc, Debreceni Egyetem Népegészségügyi Kar Családorvosi és Foglalkozás-egészzégügyi Tanszék \\ *MTA IX. Osztály Statisztikai és Jövőkutatási Tudományos Bizottság
}

\begin{abstract}
ÖSSZEFOGLALÁS
Szerzők a hazai egészségügyi alapellátás 1992. július 1-jén bevezetett reformja utáni negyed évszázad eredményeit ismertetik a tudásmegosztás szempontjából. Egyértelműen bizonyítható, hogy a praxisok önállóvá válásával az egészségügyi alapellátás megítélése kedvezővé vált, a családorvosok tekintélye megnőtt. Ennek megerősítésére szolgált a huszonöt évvel ezelőtt megkezdett győri kezdeményezésű Alapellátási Szabadegyetem képzési és továbbképzési forma, mely folyamatosan és rendszeresen tartott, akkreditált szakmai továbbképzései révén a tudásmegosztás országos modelljévé vált. A háziorvosok a továbbképzéseken üléselnökként, előadóként és moderátorként kollegiális kapcsolatot alakítottak ki; szakmai ismereteik bővítésére az elhangzott anyagok részletes dokumentációja a továbbképzéseiket segítette, továbbá helyi, regionális szinten szervezve a költségmegtakarítás is igen jelentős volt. A szerzők felhívják a figyelmet arra, hogy a szakmában jelenleg is aktívan dolgozó családorvosok életkora nagyon magas, utánpótlásuk biztosítása egyre nagyobb gondot jelent. Így az elkövetkező évek legfontosabb feladata lesz a praxisfinanszírozás jelentős arányú növelése, a fiatal orvosok számára kedvező lehetőségek biztosításával a letelepedéshez. Ugyanakkor az is feladat, hogy a családorvosok nyugdíjba vonulása egy szakmai életút méltó lezárása lehessen.
\end{abstract}

\section{ABSTRACT}

This paper discusses the results of the 25 years of the 1992 primary care system reform in Hungary from knowledge sharing approach. It has been proven that as the health practices became independent the primary care system developed better judgement, the prestige of the doctors has grown. Now the 25-year-old Open University of Primary Care - a form of professional studies - has become a model in Hungary because of its systematic, accredited education and 
knowledge sharing forms. The general practitioners - as chairmen, presenters and moderators made collegial contacts with each other; the plenteous documentation of the presentations has helped them after the courses, and additionally, there is a great cost saving factor because of the regional organizing. The authors emphasize that the age of the practitioners is very high, the need for the renewal of the profession is stronger than ever. In the years coming the greatest tasks will be the increase of medical practice financing and guaranteeing possibilities for the young doctors to settle. It is important at the same time for retiring family doctors to be offered dignified ways they deserve ending their professional career.

Kulcsszavak: képzés és továbbképzés, családorvos, költség-haszon elemzés, indikátorok, praxisfinanszírozás, tudásmegosztás

Keywords: training and further education, general practitioner, cost/benefit analysis, indicators, medical practice financing, knowledge sharing

\section{BEVEZETÉS}

Az 1992-ben Magyarországon bevezetett egészségügyi alapellátási reform része volt a körzeti orvosi rendszer háziorvosi rendszerré való átalakítása, és az ennek keretében működő vállalkozások engedélyezése. Az új rendszer nemcsak szakmai, hanem számos más jellegü (gazdasági, jogi stb.) ismeretet is igényelt. A tanulmányunkban azt mutatjuk be, hogyan segítette a háziorvosok képzését és továbbképzését a huszonöt éve müködő Alapellátási Szabadegyetem Győrött (Schmidt, 1996, 2000, 2001a, 2001b, 2004a, 2004b).

\section{A CSALÁDORVOSRENDSZER KIALAKULÁSA}

1990 előtt a kelet-közép-európai országokban az állami egészségügyi ellátás modellje müködött. A rendszert a központi irányítás, az állami tulajdonban lévő egészségügyi szolgáltatók, az ingyenes ellátásra szóló általános jogosultság, a beteg választási szabadságának hiánya, a krónikus hiány állapota (forráshiány, a megfelelő müszerek, gyógyszerek hiánya, zsúfoltság, kényszerhelyettesítések), a szolgáltatások alacsony minősége jellemezte (Schmidt-Simon, 1989; Balogh, 2000). A 90-es évek jellemzője volt a korábbi, állampolgári jogon járó központosított egészségügyi modellről a társadalombiztosításon alapuló finanszírozásra való áttérés (Borbás et al., 2005). „A világ minden részén máig vitatéma, hogy az egészségügyi rendszer problémáira a piaci elemek erősítése a megoldás, vagy éppen a nagyobb állami szerepvállalás a társadalmi egyenlőtlenségek enyhítése érdekében" (Garai, 2010; Schmidt, 1995). 
Az összes kelet-közép-európai országban lezajlott rendszerváltozást követő reformok során a korábbi körzeti orvosi rendszer helyett háziorvosi rendszer alakult ki, új jogviszonnyal és finanszírozással. A háziorvos tulajdoni állapota és jogállása szerint többféle forma jött létre (1. táblázat).

1. táblázat. Alapellátás: háziorvosok tulajdoni és jogállása Kelet-Közép-Európában

\begin{tabular}{|c|c|}
\hline Csehország & $\begin{array}{l}\text { Az alapellátást nyújtó orvosok többsége magánorvosként dolgozik. } \\
\text { Csoportpraxisban az orvosok az egészségügyi központokban vagy olyan } \\
\text { szakorvosi rendelökben dolgozhatnak, amelyek a szakellátás mellett } \\
\text { alapellátást is nyújtanak. }\end{array}$ \\
\hline Észtország & $\begin{array}{l}\text { Vállalkozó, önállóan vagy csoportpraxisban tevékenykedő és az } \\
\text { Egészségbiztosító Pénztárral szerződésben álló speciálisan képzett, } \\
\text { ún. családorvosok hálózata. }\end{array}$ \\
\hline Lengyelország & $\begin{array}{l}\text { Egyéni vagy csoportos praxisban dolgozó háziorvosok, illetve ápolónőkből } \\
\text { és szülésznőkből álló praxisok. } \\
\text { Állami és privát praxis. }\end{array}$ \\
\hline Lettország & $\begin{array}{l}\text { Többsége állami, önkormányzati tulajdon, növekvő privát egyéni vagy } \\
\text { csoportpraxis. 1992-ben nyert létjogosultságot a háziorvosi ellátás önálló } \\
\text { vagy közös praxison alapuló modellje. }\end{array}$ \\
\hline Litvánia & $\begin{array}{l}\text { Többsége állami, önkormányzati irányítással működik. Alapellátás } \\
\text { magánrendelőben magánorvosok által is nyújtható. Ennek formája } \\
\text { többségében egyéni vagy kisebb, orvosi tulajdonban lévő csoportpraxis. }\end{array}$ \\
\hline Magyarország & $\begin{array}{l}\text { Vállalkozó háziorvosok praxisban (a körzeti orvosi rendszert 1992-ben } \\
\text { háziorvosi szolgálattá alakították). }\end{array}$ \\
\hline Szlovákia & Privát praxis. \\
\hline Szlovénia & $\begin{array}{l}\text { Állami és privát praxis (egyéni és csoport): } 1992 \text { óta lehetőség van privát } \\
\text { háziorvosi praxis létesítésére is az önkormányzati rendelők bérlése mellett, } \\
\text { így a lakosság alapellátását állami szolgáltatók és magánorvosok egyaránt } \\
\text { biztosíthatják. }\end{array}$ \\
\hline
\end{tabular}

(Borbás et al., 2005 alapján saját szerkesztés)

Az önálló gazdálkodás lehetősége miatt a vállalkozóvá vált háziorvosoknak a finanszírozás gazdaságosabb beosztására lett lehetőségük; a piaci hatások érvényesülhettek gazdálkodásukban is. Az egészségügyi alapellátás reformja 1992. július 1-jével indult el Magyarországon (6/1992. III. 31. NM rendelet a háziorvosi és házi gyermekorvosi szolgálatról, URL1). A privatizáció folyamata 1992-ben többek között a háziorvosi vállalkozások engedélyezésével kezdődött. Kezdetben még kevés családorvos választotta a vállalkozási formát. Az országos átlaggal ellentétben, Győr-Moson-Sopron megyében 1993-ban már 60\%-uk, 1994. I. negyedévében már 90\%-uk élt a lehetőséggel. 
A háziorvos ekkor még nem lett tulajdonosa a rendelönek, a berendezésnek és egyéb felszerelésnek, de az Egészségbiztosítási Pénztárral kötött szerződés alapján önmaga látta el vállalkozóként a praxishoz kötődő feladatokat. Majd az 1998-ban megalakult kormány alatt vált teljessé a privatizáció. A rendszer gazdaságosabbá tételének másik lépése volt a normatív teljesítményelvü finanszírozás bevezetése. Ezen az elven a háziorvoslás esetében a per capita rendszert vezették be, vagyis az orvos a hozzá bejelentkezett betegek száma után kap térítést (Garai, 2010).

A háziorvosok és a házi gyermekorvosok száma az elmúlt évtizedekben hathétezer között alakult, és 1998 óta kismértékben ugyan, de folyamatosan csökken, miközben a leterheltségük - az egy orvosra jutó lakosok száma és a betegforgalom - fokozatosan növekszik (2. táblázat, 1. és 2. ábra) ${ }^{1}$.

2. táblázat. A háziorvosi és házi gyermekorvosi ellátottság, leterheltség, 1990-2016 (fő)

\begin{tabular}{|c|c|c|c|c|c|}
\hline Megnevezés & 1990 & 2000 & 2005 & 2010 & 2016 \\
\hline Háziorvosok száma & 4537 & 5159 & 5018 & 4926 & 4755 \\
\hline $\begin{array}{l}\text { Egy háziorvosra jutó bejelentkezett lakosok } \\
\text { száma }\end{array}$ & 1975 & 1647 & 1717 & 1745 & 1832 \\
\hline $\begin{array}{l}\text { Egy háziorvosra jutó } 60 \text { éves és idősebb } \\
\text { lakos }\end{array}$ & 435 & 384 & 430 & 464 & 538 \\
\hline Egy háziorvosra jutó évi betegforgalom & 9599 & 10287 & 11715 & 11580 & 11898 \\
\hline Házi gyermekorvosok száma & 1420 & 1570 & 1571 & 1525 & 1444 \\
\hline $\begin{array}{l}\text { Egy házi gyermekorvosra jutó bejelentkezett } \\
\text { gyermek }\end{array}$ & 995 & 951 & 939 & 945 & 981 \\
\hline $\begin{array}{l}\text { Egy házi gyermekorvosra jutó évi } \\
\text { betegforgalom }\end{array}$ & 6184 & 6703 & 6780 & 6969 & 7232 \\
\hline Háziorvosok, házi gyermekorvosok száma & 5957 & 6729 & 6589 & 6451 & 6199 \\
\hline $\begin{array}{l}\text { Egy háziorvosra és házi gyermekorvosra jutó } \\
\text { lakosok száma }\end{array}$ & 1765 & 1516 & 1529 & 1548 & 1581 \\
\hline
\end{tabular}

KSH: Egészségügyi statisztikai évkönyv, 2016 (ksh.hu)

\footnotetext{
${ }^{1}$ Részletesebb adatokat lásd a Mellékletben.
} 


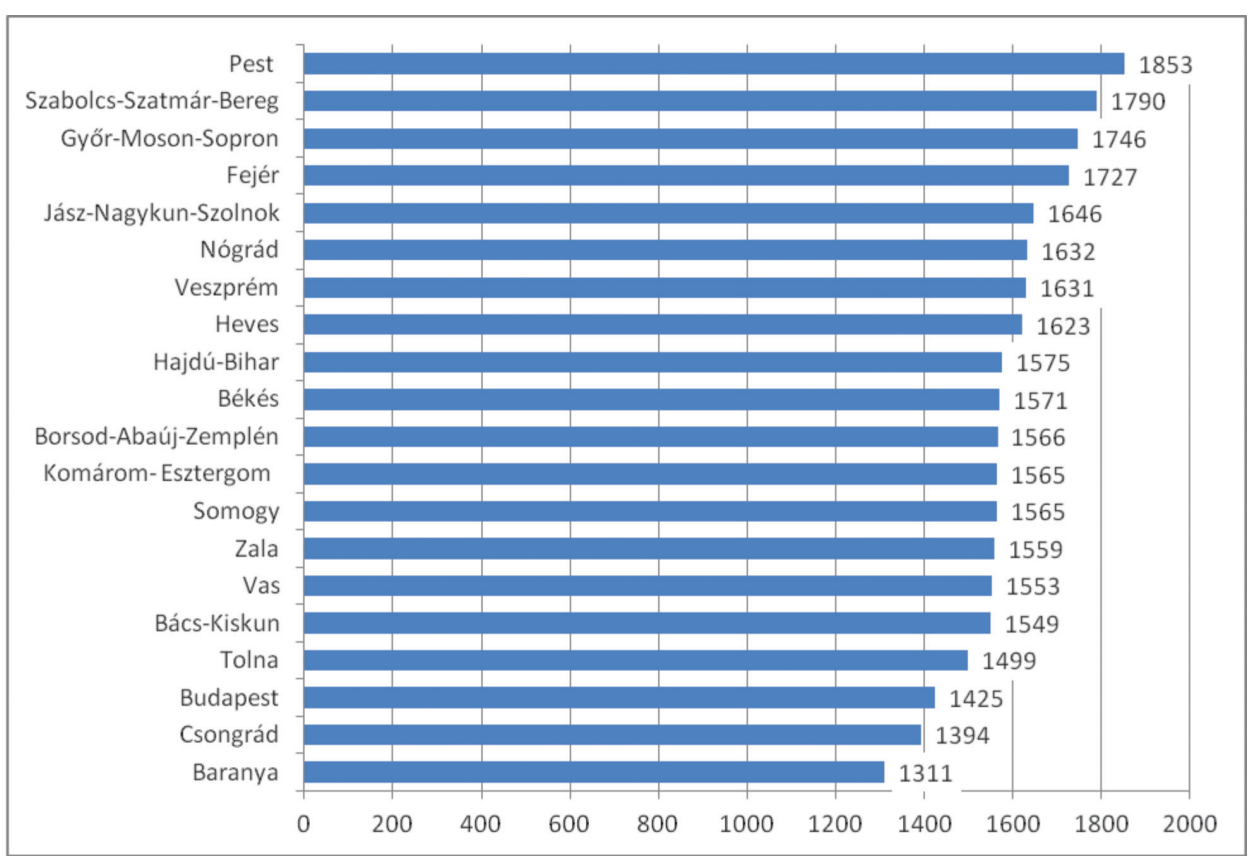

1. ábra. Egy háziorvosra és házi gyermekorvosra jutó lakosok számának megyénkénti sorrendje, 2016 (fö) (KSH: STADAT [URL3] alapján saját szerkesztés)

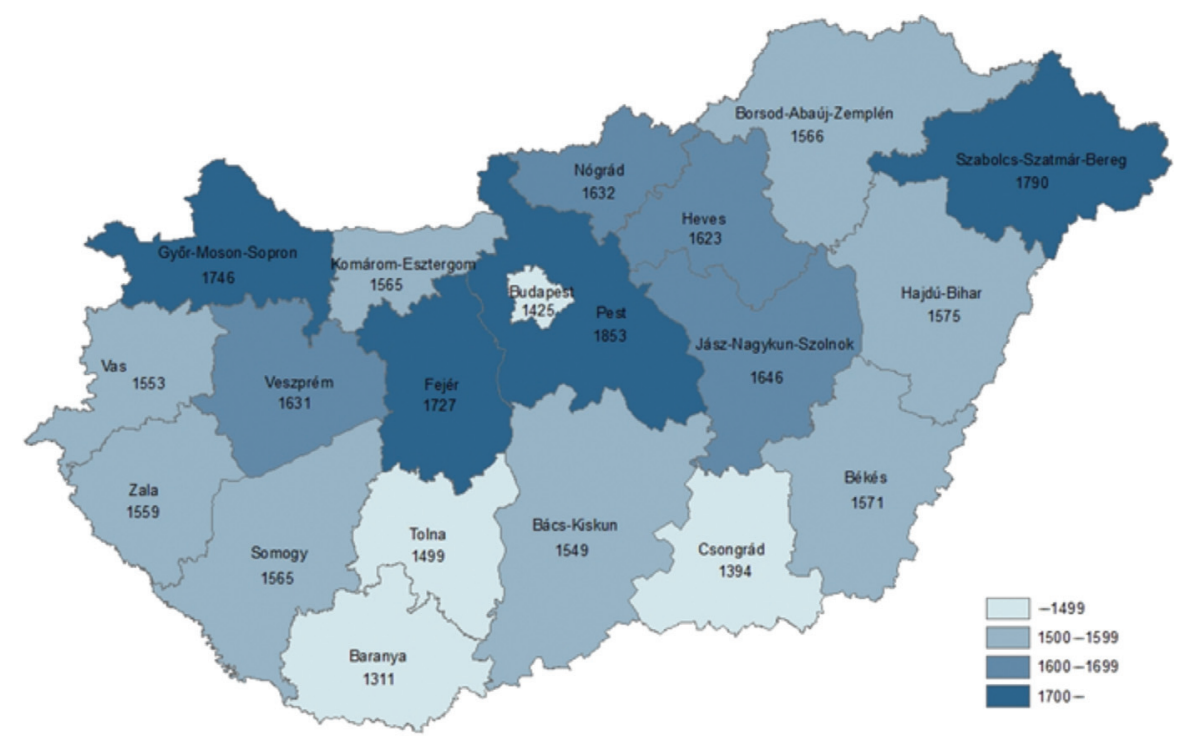

2. ábra. Egy háziorvosra és házi gyermekorvosra jutó lakos megyénként, 2016 (fö)

(KSH: STADAT [URL3] alapján saját szerkesztés) 
A településstruktúra (főváros, nagyváros, kisváros, község) is jelentősen befolyásolja az egy orvosra jutó lakosságszámot, főként felnőtt háziorvosok esetében. Fontos indikátor, hogy azokban a megyékben, ahol nagy az orvoselvándorlás, illetve orvoshiány miatt nincs mindennap háziorvosi, illetve házi gyermekorvosi rendelés, ezeken a településeken élők inkább veszik igénybe a sürgősségi/ügyeleti ellátást, még ha annak elérhetősége több kilométer megtételét is megköveteli.

A családorvosi rendszer kialakításától a hazai alapellátás minőségi megújítását várta mindenki. A praxisok önálló müködésével a háziorvoslás rangja, a családorvoslás presztízse pozitív változáson ment át. Az alapellátási reform során kiadott jogszabály kötelezővé tette a rendszerben dolgozók számára 1998. december 31-ig bezárólag a szakorvosi képesítés megszerzését háziorvostanból. Ez alól csak a legalább huszonöt éve praxisban lévők kaphattak felmentést, illetve a minimum tíz éve körzetben dolgozó belgyógyászok. 1992-ben a rendszerben dolgozók negyedének volt csak háziorvosi szakképesítése, másik negyedének egyéb klinikai szakvizsgája, és körülbelül az orvosok felének semmilyen szakvizsgája nem volt. Ez az átképzési igény hatalmas oktatási feladatot jelentett a 90 -es évek második felében létrehozott, akkor még öt családorvosi tanszéknek (Rurik et al., 2008; Rurik, 2009). Az átképzés nem érintette a gyermek-háziorvosokat, hiszen itt eleve csak szakorvosok rendelhettek.

A 90-es évek második felében az akkori egészségügyi „reformok” következtében sok kórházi orvos is az alapellátásban helyezkedett el, ami szintén jó hatással volt a szakmai színvonalra. A korábban „körzeti orvos” elnevezés „családorvossá" történt változtatásával nemcsak a név változott meg, hanem a családorvoslás szakmai tekintélye is jelentősen megnőtt, amit az elmúlt negyedszázad eredményei egyértelmúen igazolnak (Schmidt-Menyhárt, 2005). A háziorvosok tevékenysége önállóbbá vált, felelősségük megnőtt: kiemelt érdekük a praxisukhoz tartozó betegek gyógyítása, gondozása és rehabilitációja. Hazai és nemzetközi kongresszusi részvételeiket, szakkönyvvásárlásaikat és a számítógépes rendszer beszerzéséhez szükséges kiadásaikat praxisuk finanszírozásából tudták fedezni (Márton-Illyés, 1999 Márton et al., 2000a, 2000b).

Köztudott, hogy a magyar orvosegyetemi képzés az alapellátás reformja előtt is nagyon elismert volt, nemzetközi szinten (is), de a körzeti orvosok szerepe és munkája számos esetben negatív megítélése alá esett, képzésük, továbbképzésük rendszerszinten nem volt biztosítva. Mivel a családorvosok nagyon leterheltek - napi családorvosi munkájuk mellett ügyeleti, sokszor sürgősségi ellátást is biztosítanak -, a képzéseken és továbbképzéseken való részvétel számukra komoly nehézséget jelentett. Ezért úgy érezték a győri Alapellátási Szabadegyetem alapítói, hogy a képzés-továbbképzés új formáját kell kialakítani, amelynek a segítségével a legújabb szakmai információk is eljutnak a családorvosokhoz. 


\section{TUDÁSMEGOSZTÁS}

A gyorsan változó környezethez való alkalmazkodás a versenyképesség legfontosabb feltétele. Alkalmazkodni viszont csak az ember tud, és nem maga a szervezet. A széles körü kutatások és a mindennapi gyakorlat eme tapasztalata eredményezte, hogy ma a munkáját végző emberben látjuk a legfontosabb értéket.

A 7S-modell megalkotása a McKinsey cég munkatársai - Tom Peters és Robert Waterman - nevéhez köthetö (3. ábra).

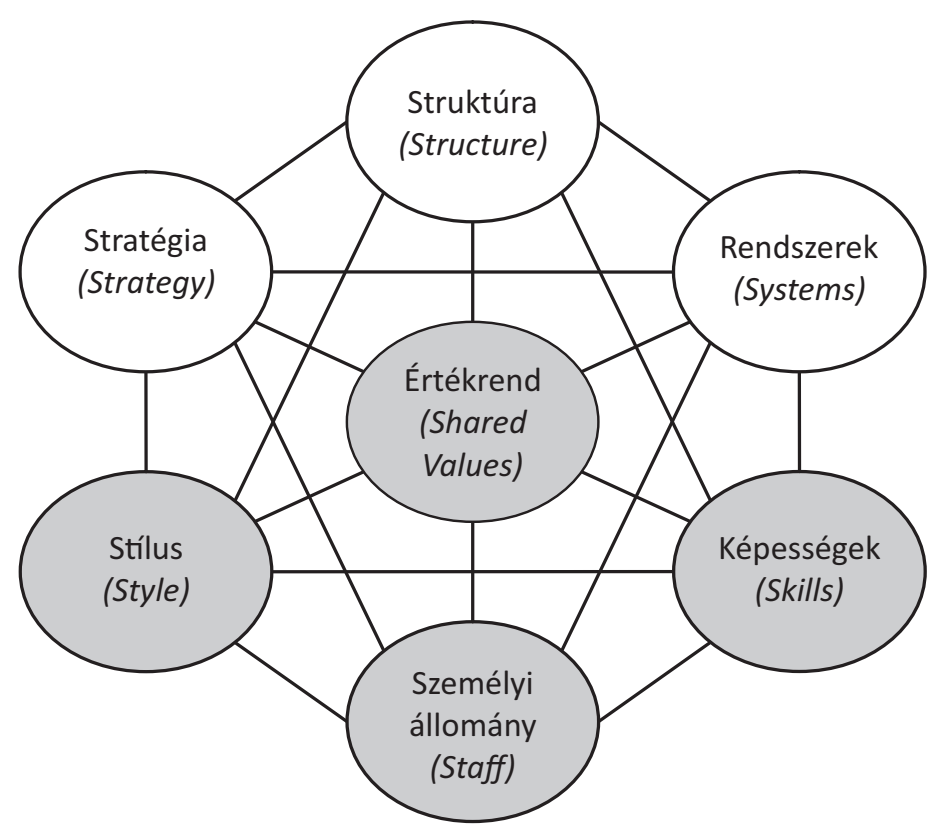

3. ábra. 7S-modell (Peters és Waterman alapján saját szerkesztés)

Azt kutatták, hogy mitől sikeresek ismert és kevésbé ismert amerikai vállalatok. Arra a következtetésre jutottak, hogy minden sikeresnek ítélt vállalat rendelkezik egy csak rá jellemző, nagyon erős kultúrával, mely már nagyon mélyen él az ott dolgozókban. Szintén a kutatás eredményeként felállítottak egy modellt, mely a szervezeti kultúra szerkezetét és szervezeti kapcsolatrendszerét mutatja be. A McKinsey-féle 7S-modell elnevezése a hét tényező angol elnevezésének kezdőbetüiből adódik. Két csoportra osztják a tényezőket: az ún. kemény tényezők (stratégia, struktúra, rendszerek) mellett fontos szerepük van a sikerben az ún. lágy tényezőknek (stílus, személyi állomány, képességek és értékrend) (HeidrichSzegedi, 2004; Heidrich, 2011; Heidrich, 2013). 
Karl Erik Sveiby 1997-ben publikált, híressé vált müve, a The New Organizational Wealth: Managing and Measuring Knowledge-Based Assets a tudásmenedzsment alapkönyve (magyarul Szervezetek új gazdagsága: a menedzselt tudás címen jelent meg 2001-ben). A változásokhoz való alkalmazkodás során a másik tudásának megszerzése és a saját tudásunkhoz való hozzáadása szinte mindig gyorsabb és hatékonyabb, mint valamilyen merőben új megoldás kitalálása. A versenyképességnek ezért fontos eleme a tudás szabad áramlása. A gyakorlatban mégsem múködik igazán - sem a gazdaság, sem pedig a közoktatás világában (Gönczöl, 2009).

„A legkülönbözőbb fejlesztési programokban a továbbképzés a felkészülés egyik vagy talán legfontosabb eszköze, maga mögé utasítva a tanácsadást, mentorálást stb. Ennek elsősorban az az oka, hogy a továbbképzés fajlagosan olcsóbb, ugyanolyan ráfordítással sokkal több szakembert lehet közvetlenül elérni. A továbbképzések célja, hogy a kurzusokon megszerzett tudás beépüljön a napi gyakorlatba." (URL2)

A tudás megosztásának számos gátló tényezőjét tárták fel: önzés, bizalmatlanság, korábbi rossz tapasztalatok, időhiány, szervezeti korlátok és hatalomféltés.

A tudásmenedzsmenttel foglalkozó szakemberek ma úgy látják, hogy a szakmai közösségek a tudásmegosztás igazi motorjai, amelyek le tudják küzdeni az említett akadályozó tényezőket. Tomka János szerint a szakmai közösségek építőelemei három területen azonosíthatók: szakterület, közösség és gyakorlat. A szakterületen betöltött közösségépítő hatást abban látja többek között, hogy „közös alapot és közös identitásérzést hoz létre, legitimálja a közösséget, a tagokat részvételre és közremüködésre inspirálja, útmutatást nyújt a tanuláshoz és értelmet ad a tetteknek”. A szakmai közösség egyben ,a tanulás közösségi szövetét biztosítja, segíti a kölcsönös tiszteleten és bizalmon alapuló interakciókat és kapcsolatokat, bátorítja az ötletek feltárását, az egyéni hiányok felfedését, a nehéz kérdések megfogalmazását, serkenti a másokra való figyelési képességet, a valahová tartozás tanulást ösztönző érzését adja". Míg a gyakorlati szerepet úgy azonosítja, hogy a szakmai közösség ,,a közösség tagjai által megosztott közös keretek, ötletek, eszközök, információk, stílusok és dokumentumok együttese" (Tomka, 2005, 89.).

A tanulmányunkban azt vizsgáltuk, hogyan sikerült mindezt megvalósítani a huszonöt éve müködő Alapellátási Szabadegyetem családorvosképzés és -továbbképzés keretében Győrött.

\section{ALAPELLÁTÁSI SZABADEGYETEM GYŐRÖTT - 25 ÉV}

Az egészségügyi alapellátás 1992-ben kezdődő reformját megelőző évben a családorvosok részére - győri kezdeményezésként - folyamatos és rendszeres továbbképzést szervezett az Egészséges Nemzedékért Alapítvány Alapellátási Sza- 
badegyetem néven. Ez a felkészülést jelentette a családorvosi vállalkozási formák megismertetésére:

- gazdasági és közgazdasági ismeretek tárgyalása, a szakma legkiválóbb elöadóival;

- könyvelési szempontok szakirányú képzéssel;

- és az akkor még gyermekcipőben járó informatikai rendszerek bemutatása, gyakorlati képzéssel.

Az Alapellátási Szabadegyetem iránt az elmúlt évek során folyamatosan mind nagyobb lett az érdeklődés. A huszonöt éve müködő program sikere azt igazolja, hogy a szakmai közösségek a tudásmegosztás igazi motorjai (Schmidt, 1996, 2000, 2001a, 2001b, 2004a, 2004b). A rendezvényeken átlagosan 120-150 kolléga vesz részt.

A havonta egy, a hónap 3. szombatján szervezett továbbképzések egyben a továbbképzéshez szükséges kreditpontokat is biztosítják, segítve a családorvosok szakmai elvárásoknak is megfelelő ismeretekkel való ellátását. Ennek a képzési formának a segítségével naprakész információkat kapnak a kollégák, amit a gyorsan elévülő szakkönyvekből - elfoglaltságuk miatt - nem tudnának elsajátítani, egyben továbbképzéseinknek a közösségi és az orvosi kapcsolatok kiépítésében is fontos szerepe van.

A folyamatos és rendszeres képzés keretében általában az Egészséges Nemzedékért Alapítvány által koordinálva szervezték a tudományos szimpóziumsorozatot, melybe bekapcsolódott a Semmelweis Egyetem Családorvosi Tanszéke, később a Pécsi Tudományegyetem és a Szegedi Tudományegyetem Általános Orvosi Kar Családorvosi Intézete is. Az egyetemi oktató intézmények jelentős segítséget nyújtottak az akkreditációban a kreditpontok biztosításával.

Ez a képzési-továbbképzési sorozat huszonöt éve folyamatosan müködik. A továbbképzések komoly előnye, hogy a résztvevők részvételi díj nélkül látogathatják a rendezvényeket. Kiemelt együttmüködő szervezetnek bizonyult Győr városa, Győr-Moson-Sopron megye Önkormányzata, később a Megyei Orvosi Kamara is. A kihelyezett üléseket leszámítva, a Győri Városháza patinás díszterme méltó helyszínként szolgált.

Az elmúlt huszonöt év során a rendezvényeket szemeszterenként öt, így tanévenként tíz alkalommal szervezték meg. A családorvosokon kívül mind nagyobb számban vesznek részt ezeken kórházi orvosok, ÁNTSZ-es és egészségbiztosítási szakemberek, nemcsak Győr-Moson-Sopron megyéböl, hanem a térség öt - Vas, Zala, Veszprém, Komárom-Esztergom és Fejér - megyéjéből is. Jelentős háttérsegítséget nyújtott a továbbképzésekhez, hogy folyamatosan kiadványokat jelentettek meg a továbbképzések anyagaiból, melyek első kötete az Önkormányzati Háziorvosi Útmutató volt (Schmidt, 1992).

A szervezők legfontosabb célja: naprakész információk biztosítása háziorvosok számára, illetve azoknak az ismereteknek az átadása, melyeket egyetemi tanul- 
mányaik során nem tanultak vagy nem tanulhattak (Arnold, 2000). Az általános tájékoztatókon túl, a diagnosztika és terápia tárgyköre mellett mind jobban előtérbe kerültek az egészségügy gazdasági, közgazdasági, jogi és etikai kérdései, valamint - kihelyezett képzés során - a társadalombiztosítással foglalkozó továbbképzés-sorozat. Az informatikai ismeretek széles körü elterjedésével nemcsak a kollégák, hanem a praxisban dolgozó munkatársak is aktív szerephez jutottak. Ez is hozzájárulhatott ahhoz a kedvező tendenciához, hogy az $\mathrm{OEP}^{2}$ által kötelezövé tett elektronikus jelentések, továbbá az adminisztratív tevékenységek jelentős része elektronikusan kerül továbbításra. Ennek terjedelme és részletessége azonban sokkal nagyobb hazánkban, mint más európai országokban (Rurik-Kalabay, 2008, 2009).

1996 és 1998 között a háziorvosok és az egészségügyi szakdolgozók a Széchenyi István Egyetem (jogelődjében) fakultatív informatikai képzésen vettek részt, amikor egységessé vált az informatika kötelező használata a receptek írásánál és a jelentéseknél. Ez az országban egyedülálló, a praxisok részére térítésmentes, az egyetem által felajánlott képzés volt.

\section{A TUDÁSMEGOSZTÁS HATÁSÁNAK VIZSGÁLATA}

A háziorvosok körében végzett kérdőíves felmérés eredményei alapján elmondható, hogy igénylik ezt a képzési-továbbképzési rendszert. Megtisztelő számukra, hogy az Alapellátási Szabadegyetem keretében üléselnökként, illetve előadóként vehetnek részt, $\mathrm{s}$ a rendezvények során elsajátított ismeretek akár többhetes, tankönyvből történő felkészülést helyettesíthetnek (Schmidt, 2000).

\section{A résztvevők számának alakulása}

Eddig összesen 225 szakmai továbbképzésre került sor Alapellátási Szabadegyetem formájában. Az átlagos látogatottsági számokat alapul véve (120-150 fö/ rendezvény, átlagosan 130 fö) a résztvevők száma az elmúlt huszonöt évben 29250 fö volt.

\section{Költségmegtakarítás a résztvevők számára}

Előzetes költség-haszon vizsgálatok során bizonyítást nyert, hogy a Győr-Moson-Sopron megyében kezdeményezett, országos modellként szolgáló „helyben pontszerzo"” háziorvosi képzés-továbbképzés milyen jelentős idő- és költségmegtakarítással járt a résztvevők számára (Schmidt-Végh, 2003; Hargitai, 1992).

²017. január 1. óta Nemzeti Egészségbiztosítási Alapkezelő (NEAK). 
A korábbi évek elemzései azt mutatják, hogy a családorvosok számára az anyagi megtakarítások egyre jobban érzékelhetők napjainkban, hiszen mind a kongresszusok részvételi költségei (regisztrációs díj, szállásköltség, útiköltség, étkezés stb.), mind pedig az üzemanyagköltségek hatványozottan emelkedtek, és ezek a helyben szervezéssel részben megtakaríthatók. Emellett az utazásra fordítandó idő is a töredékére csökken.

Egy före számítva egy átlagos, fóvárosban tartandó továbbképzés költségeit (átlagosan 19000 Ft/fó) a megtakarítás az elmúlt negyed században (29 250 fő × 19000 Ft/fö) $\mathbf{5 5 5} \mathbf{7 5 0} 000$ forintra becsülhető.

\section{Előadók és témakörök}

Az eddigi 225 rendezvény során 2300 előadás hangzott el. A 2300 szakmai előadáson a legváltozatosabb témakörök szerepeltek (4. ábra).

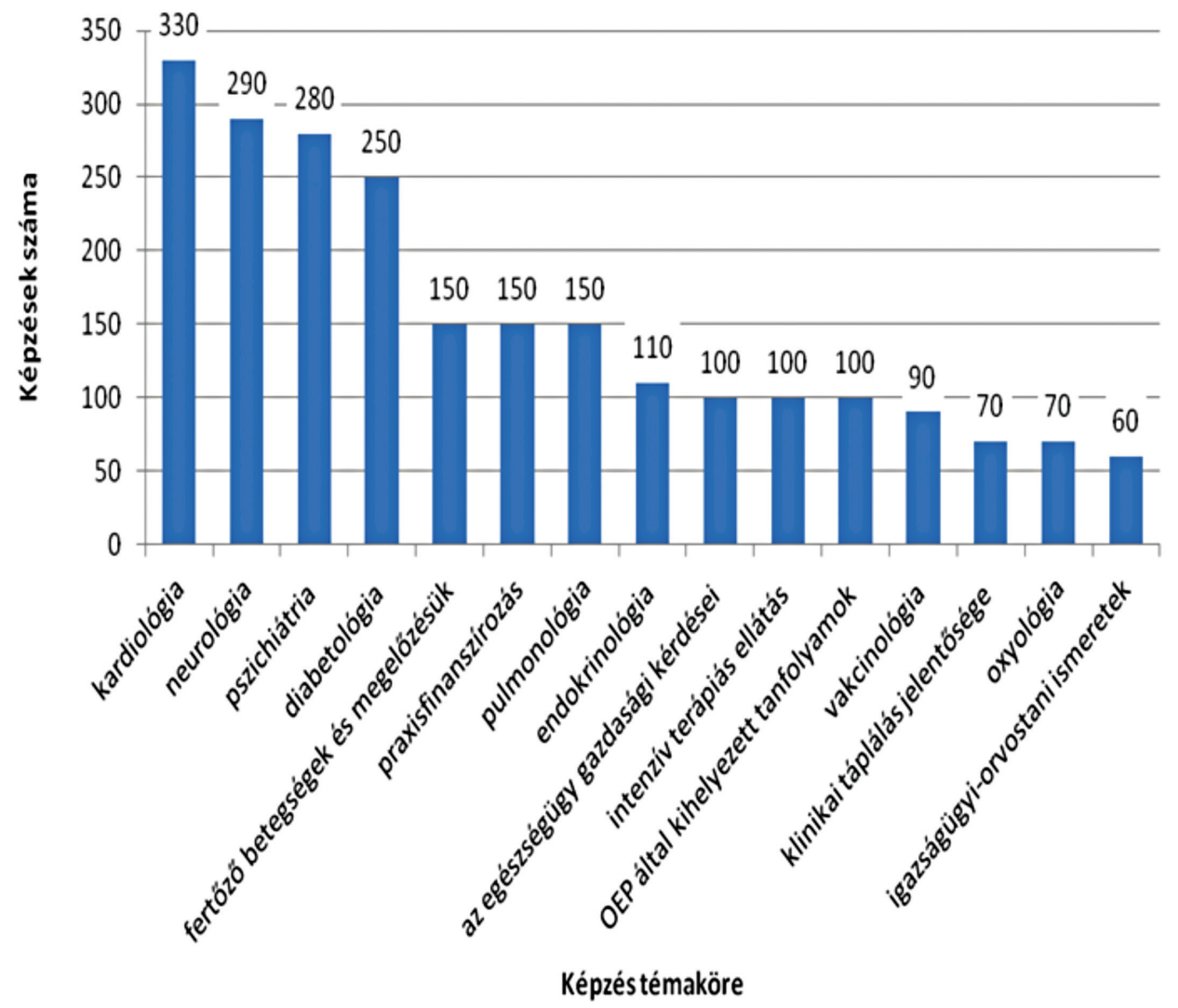

4. ábra. A szakmai előadások száma és témakörei a huszonöt év során (saját szerkesztés) 
A legtöbb előadás a kardiológia szakterületéről hangzott el. Az e terület iránti érdeklődés azzal magyarázható, hogy az elmúlt évtizedekben folyamatosan észlelhető volt a mortalitással járó kardiológiai megbetegedések és elváltozások magas aránya. A korszerủ müszeres beavatkozások, orvostechnikai fejlesztések és a csúcstechnológiát jelentő képalkotó diagnosztika látványos pozitív eredményeket hoztak. Az előadások 10-12\%-át tette ki a neurológia, ezen belül is a stroke témakör. A pszichiátria, a pulmonológia (a COPD-vel együtt) és a diabetológia területét érintő prezentációk a prevencióra, szürésre, gondozásra és utógondozásra tértek ki. A szimpóziumok további témái voltak a fertőző betegségek és azok megelőzési lehetőségei, a praxisfinanszírozás, az endokrinológia, az egészségügy gazdasági és közgazdasági kérdései, az intenzív terápiás ellátás, az OEP által kihelyezett tanfolyamok és a vakcinológia. Helyet kapott az előadások között a klinikai táplálás jelentősége, az oxyológia elméleti és gyakorlati alkalmazása a napi háziorvosi gyakorlatban és az igazságügyi-orvostani ismeretek témája is. 2017ben új tudományterületként jelent meg a humán makroökológia (Simai, 2016).

\section{Együttmúködő partner intézmények}

Az elmúlt negyedszázad 225 rendezvényére visszatekintve elmondható, hogy számos gyümölcsöző együttmüködés alakult ki. Ennek bizonyítéka, hogy a Semmelweis Egyetem Családorvostani Tanszéke, illetve a Pécsi és a Szegedi Tudományegyetem Családorvosi Intézetei által delegált szakmai előadók, továbbá a Győri Petz Aladár Megyei Oktató Kórház több kiváló munkatársa tartott nagy sikerrel előadásokat. A képzésbe bekapcsolódott a Széchenyi István Egyetem is.

2012-ben a foglalkozás-egészségügyi kötelező továbbképző tanfolyamok is beindultak. További cél a Családorvos Kutatók Országos Szervezetével való szoros kapcsolat (Stavdal, 2016; Kolláth et al., 2016; Kalmár-Balogh, 2016; SchmidtMuzsay, 2010), továbbá kapcsolatfelvétel a Debreceni Tudományegyetem Általános Orvosi Kar Családorvosi Intézettel (Kolozsvári et al., 2014).

Fontos szerep jutott a Győr-Moson-Sopron Megyei Orvosi Kamarának is, ahol a kollégák folyamatosan tájékozódhattak a továbbképzésekről. A visszajelzések, illetve a kamarai nyilvántartás alapján azon családorvosok, akik huszonöt évig folyamatosan körzetben dolgoztak, címzetes föorvosi kinevezést vehettek át a rendezvényeken.

\section{MEGBESZÉLÉS - A HÁZIORVOSLÁS JÖVŐKÉPE}

Az egészségügyi alapellátás reformja következtében minőségi változás állt be a hazai alapellátásban: körzeti orvosból háziorvos/családorvos lett, a praxisok önálló tevékenységet végeznek, a háziorvosok szakmai tekintélye jelentősen megnőtt, 
javult a minőségi munka. Az alapellátás reformját követően a praxisok finanszírozásában az „aranyévek” az 1992-1998 közötti időszak volt, ezt követően, sajnos, a praxisfinanszírozás reálértéke folyamatosan csökkent, nem követve az inflációt (Fejér, 1996; Boros, 2000). Ennek következtében az elkövetkezendö évek egyik kiemelten fontos feladata a praxisfinanszírozás igen jelentős növelése lesz. Az utóbbi években ugyan történtek kormányzati kezdeményezések, a finanszírozás láthatóan emelkedett, azonban még mindig nem éri el azt a szintet, hogy vonzóvá tegye a háziorvosi pályát.

Nagyarányú az elöregedés (3. táblázat), kevés az utánpótlás, a helyzet a gyermek-háziorvosi praxisokban még súlyosabb, igen sokan dolgoznak hetven, sőt hetvenöt év felett is teljes munkaidőben, másrészt igen nagy számban távoztak a háziorvosok külföldre, melynek egyenes következménye lett, hogy 2016-ban közel négyszáz praxis volt betöltetlen.

3. táblázat. A háziorvosok kormegoszlása, 2015. december 31.

\begin{tabular}{|c|c|c|c|c|c|}
\hline Életkor & $\mathbf{6 0}$ év alatti & $\mathbf{6 0 - 6 4}$ éves & $\mathbf{6 5 - 6 9}$ éves & $\mathbf{7 0 - 7 4}$ éves & $\mathbf{7 5}$ év feletti \\
\hline Arány, \% & 57,8 & 19,3 & 12,9 & 7,1 & 2,8 \\
\hline
\end{tabular}

Egészségügyi Nyilvántartási és Képzési Központ: Beszámoló az egészségügyi ágazati humáneröforrás 2015. évi helyzetéröl az egészségügyi ágazati humáneröforrás-monitoringrendszer alapján, 2016. 109. oldal (enkk.hu)

Az orvoshiány következtében a háziorvosok és a házi gyermekorvosok helyettesítési szolgálatainak száma megnőtt (5. és 6. ábra), tovább növelve leterheltségüket.

Ugyancsak súlyos gondot jelent, hogy mind több, évente 800-1000 magyar orvos kér szakképesítése külföldön történő elismerése céljából hatósági bizonyítványt. 2016-ban a külföldre távozó orvosok 40\%-a harmincévesnél fiatalabb, a kétharmaduk negyven év alatti volt, többségük Nyugat-Európában, föként Németországban, az Egyesült Királyságban vagy Svédországban vállal munkát, a legtöbben belgyógyász, illetve háziorvosi szakképesítés elismertetését kérték ${ }^{3}$ (enkk.hu).

A következő évek legfontosabb feladata: az egyes praxisok finanszírozásának jelentős növelése és a háziorvosi munka vonzerejének növelése. Ez utóbbihoz szükséges, hogy

- az egyetemi évek során is mind több orvostanhallgató gyakorlati ismeretei bővüljenek az alapellátás munkájával kapcsolatban;

\footnotetext{
${ }^{3}$ A hatósági bizonyítványt kérők száma a külföldi munkavállalás mérésére bizonyos korlátokkal alkalmazható (arra vonatkozóan nincs információ, hogy a kérelmezők valóban elhagyják-e az országot).
} 


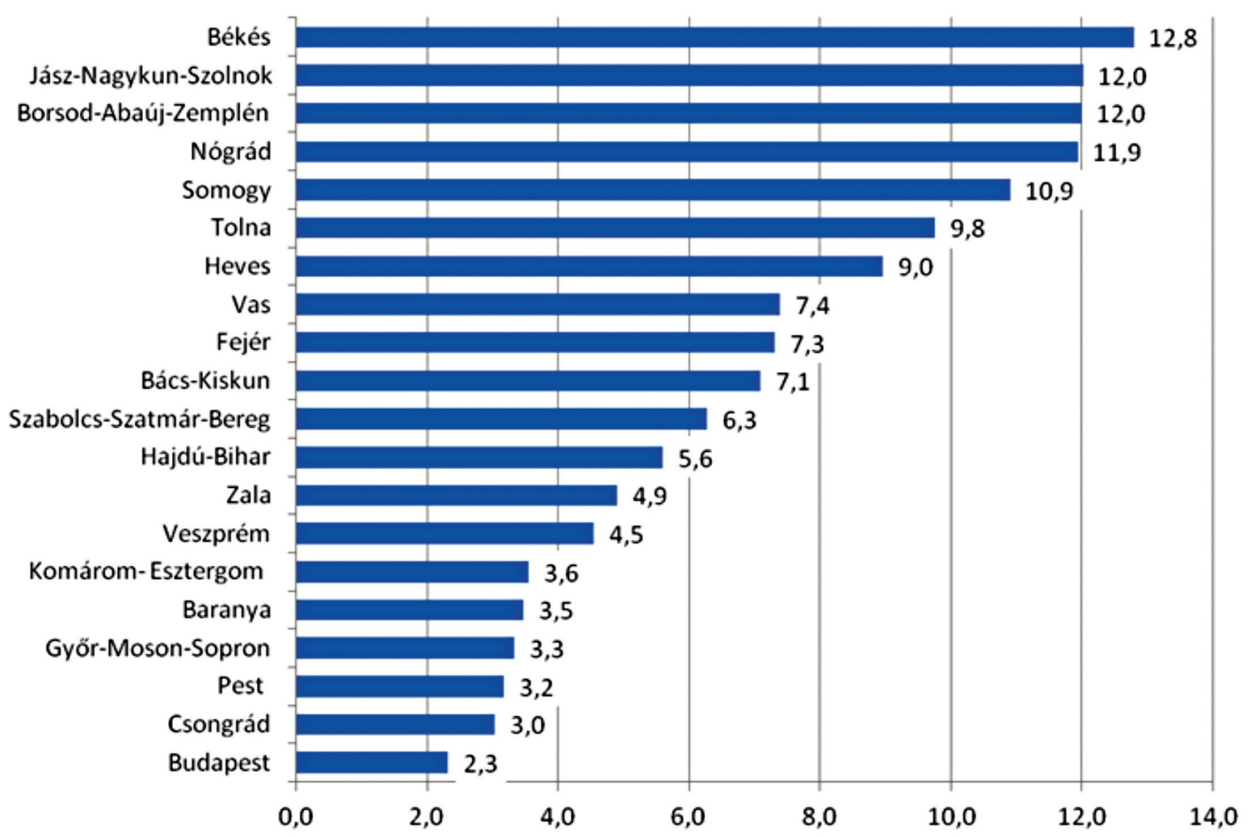

5. ábra. A háziorvosok és házi gyermekorvosok helyettesítésben ellátott szolgálatainak aránya, megyénkénti sorrend, 2016 (\%)

(KSH: Tájékoztatási adatbázis [statinfo.ksh.hu] alapján saját szerkesztés)

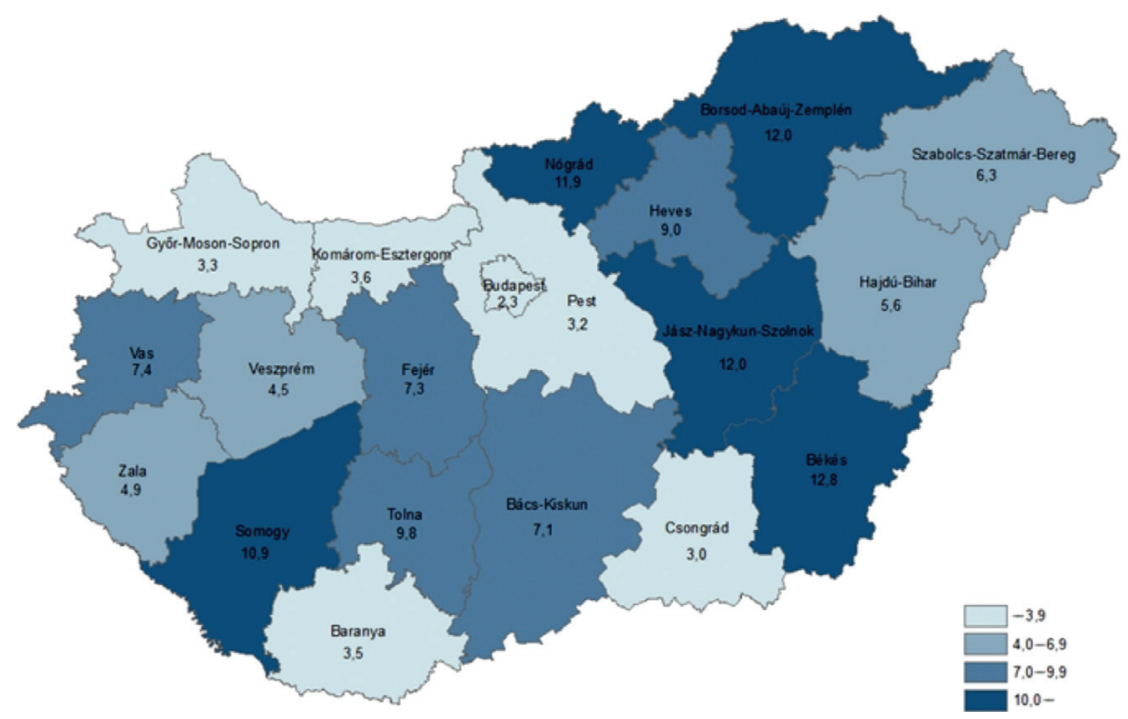

6. ábra. A háziorvosok és házi gyermekorvosok helyettesítésben ellátott szolgálatainak aránya, megyénként, 2016 (\%)

(KSH: Tájékoztatási adatbázis [statinfo.ksh.hu] alapján saját szerkesztés) 
- ezen belül a nyári gyakorlatokon is bevonjuk őket a háziorvosi munkába, és megkedveltessük velük ezt a fontos szakterületet;

- a rezidensképzés során megkedveltessük az alapellátás munkáját a rezidens kollégákkal.

Ennek hiányában, sajnos, nem várható, hogy a jelenleg betöltetlen, üres, közel $400^{4}$ praxisba új családorvosok kerülhessenek.

Az Alapellátási Szabadegyetem müködésének huszonöt éve során betöltötte és jelenleg is betölti a szakmai közösségek építőelemeinek szerepét (mind a szakterület, mind a közösségépítés, mind a gyakorlat szempontjából). Elmondhatjuk, hogy e képzési és továbbképzési rendezvénysorozat intézményesült (SchmidtKonczosné, 2017).

Ha a huszonöt éves müködést a McKinsey tanácsadó cég 7S-modellje kritériumai alapján értékeljük, elmondhatjuk, hogy

- stratégiáját tekintve küldetését, céljait és tevékenységét megvalósította (jövőbe tekintő, kreatív, rugalmas, aktív, akciókra épülö, változásorientált, tartós sikerre törekvő);

- struktúráját tekintve team forma, amelyben az Alapítvány szervezésében történő programokhoz önként csatlakozott szakemberek csoportjairól beszélhetünk (nincsenek alá- és fölérendeltségi viszonyok);

- rendszerét tekintve egymásra épülő, egymást támogató cselekvéssorról beszélhetünk, amelyben az elemek folyamattá épülnek, és a partnerek igényeinek és elvárásainak megfelelnek;

- stílusát tekintve emberikapcsolat-központú: segíti a kölcsönös tiszteleten és bizalmon alapuló kapcsolatokat, fejleszti a másokra való figyelési képességet, a szakmai közösséghez tartozás tanulást ösztönző érzését adja;

- a munkatársak - a képzések és továbbképzések előadói a szakma kiválóságai, szakértői;

- mind a szakmai, mind a speciális képességek (jövőképalkotás, minőségirányítás, a kommunikáció irányítása, értékelés, csoportmunka irányítása, kultúrateremtés, elkötelezettség erősítése) fejlesztésének teret enged;

- a közös munkát meghatározó, közösen vallott értékek: a szakmai tudás folyamatos fejlesztése, a családorvosi feladatok minél magasabb színvonalú ellátása, a szakmai közösség építése (Schmidt, 2017; Schmidt-Konczosné, 2018a, 2018b).

A 7S-modell a jövőkép megfogalmazásához is segítséget kínál, a jelen és a jövő összevetése alapján meghatározza, mely területeken kíván változásokat elérni.

²016-ban 397 szolgálatot láttak el a háziorvosok és házi gyermekorvosok helyettesítésben. 
Az alapellátás megerősítésében, minőségének egységesítésében alapvető jelentőségük van a regionális továbbképzési rendszereknek. Ezek a képzési centrumok alkalmasak arra, hogy a lokális problémákra reagálhassanak, személyes kapcsolatot tartsanak az ellátókkal, ennek megfelelően alakítva a képzés tematikáját. Mindezek mellett ez költséghatékony is. Ezért ajánljuk, hogy más régiók is - amennyiben még nincs ilyen - alakítsák ki a saját továbbképzési centrumukat.

\section{IRODALOM}

Arnold Cs. (2000): A családorvosi tanszék szerepe és helye a graduális oktatásban, szakképzésben, továbbképzésben és kutatásban. Medicus Universalis, 33, 2-6.

Balogh S. (2000): Háttéradatok a háziorvosi ellátásról I-II. Medicus Universalis, 33, 21-25., $97-$ 102.

Borbás I. - Szirmai L. - Verdes N. et al. (2005): Egészségügyi rendszerek Kelet-Európában. (ESKI füzetek 2) Egészségügyi Stratégiai Kutatóintézet, Egészségügyi Rendszertudományi Iroda, http://www.eski.hu/new3/politika/zip_doc_2005/kelet-europa.pdf

Boros P. (2000): Valóban csőd fenyegeti a társadalombiztosítást? Praxis, 9, 9-15.

Fejér L. (1996): Javaslatok a járóbeteg-szakellátás finanszírozásának változtatására. Egészségügyi Gazdasági Szemle, 34, 44-45.

Garai L. (2010): A vállalkozó háziorvosok finanszírozásának alakulása a rendszerváltás óta. $M e$ dicus Universalis, XLIII.

Gönczöl E. (2009): A tudásmegosztás formális és informális közösségei. http://www.osztalyfonok. hu/cikk.php?id=677

Hargitai S. (1992): Társadalombiztosítás, egészségügy-finanszírozás. Egészségügyi Gazdasági Szemle, 30, 410-420.

Heidrich B. (2011): Alkalmazottak vezetése. Budapest: Budapesti Gazdasági Föiskola-Digitális Tankönyvtár

Heidrich B. (2013): Alkalmazottak vezetése. Digitális tankönyvtár. http://www.tankonyvtar.hu/ hu/tartalom/tamop412A/0007_e6_alkalmazotti_vezetes_scorm/a_mckinsey_fele_7s_modell 4AAtvCLmKTCwboJZ.html

Heidrich B. - Szegedi K. (2004): Szervezeti kultúra, üzleti etika. http://publikacio.uni-miskolc.hu/ data/ME-PUB-5639/Szervezeti\%20kult.pdf

Kalmár Z. - Balogh S. (2016): Családorvosok folyamatos szakorvos képzése a Pécsi Tudományegyetemen. Családorvos Kutatók Országos Szervezete XV. kongresszusa, 2016. február 25-27. Budapest, Hotel Flamenco. Program és Összefoglalók. https://docplayer.hu/15993831-Csaladorvos-kutatok-orszagos-szervezete-xv-kongresszusa.html

Kolláth R. - Pipicz M. - Mester L. et al. (2016): Egészségtudatosság a fitnesz szakmában, illetve ülö munkahelyen dolgozók körében. Családorvos Kutatók Országos Szervezete XV. kongresszusa, 2016. február 25-27. Budapest, Hotel Flamenco. Program és Összefoglalók. https:// docplayer.hu/15993831-Csaladorvos-kutatok-orszagos-szervezete-xv-kongresszusa.html

Kolozsvári L. R. - Orozco-Beltran, D. - Rurik I. (2014): Do Family Physicians Need More Payment for Working Better? Financial Incentives in Primary. Care Atención Primaria, 46, 5, 261-264. DOI: 10.1016/j.aprim.2013.12.014, https://www.researchgate.net/publication/261602137_Do_ family_physicians_need_more_payment_for_working_better_Financial_incentives_in_primary_care 
Márton H. - Illyés I. (1999): Elvárások a családorvosi munkával szemben I. Az orvosok szemszögéböl. Medicus Universalis, 32, 63-67.

Márton H. - Illyés I. - Varga J. (2000a): Elvárások a családorvosi munkával szemben: II. A betegek szemszögéböl. Medicus Universalis, 32, 3, 123-126.

Márton H. - Illyés I. - Varga J. (2000b): Elvárások a családorvosi munkával szemben III. Az orvosok és a betegek véleményének összehasonlítása. Medicus Universalis, 33, 103-108.

Rurik I. (2009): General Practice in Europe, Hungary-2009. The European Journal of General Practice, 15, 2-3.

Rurik I. - Ilyés I. - Rinfel J. et al. (2008): Past and Present Challenges in Education and Certification of Family Physicians in Hungary. In: Ortiz, M. - Rubio, C. (eds.): Educational Evaluation: $21^{\text {st }}$ Century Issues and Challenges. New York: Nova Science publisher, 407-416.

Rurik I. - Kalabay L. (2008): A háziorvosok adminisztratív és adatszolgáltatási kötelezettségei Európában. Összehasonlító elemzés a magyarországi kötelezettségekkel. Orvosi Hetilap, 149, 867-872. https://bit.ly/2FoMMtH

Rurik I. - Kalabay L. (2009): Primary Health Care in the Developing Part of Europe. Medical Science Monitor, 15, 7, 78-84. https://www.medscimonit.com/download/index/idArt/869692

Schmidt P. (szerk.) (1992): Önkormányzati Háziorvosi Útmutató. Győr: Hazánk Könyvkiadó Kft.

Schmidt P. (1995): Zur Reforms des Ungarischen Gesundheitssystems und ihren Auswirkungen. In H-U-Deppe: Zur Aktuellen Entwicklung der Gesundheitspolitik in Ungarn. Arbeitspapier Nr. 15/1995. Frankfurt am Main

Schmidt P. (1996): Alapellátási Szabadegyetem Győr-Moson-Sopron megyében - egy országos modell a háziorvosok képzésében és továbbképzésében. Orvosi Hetilap, 137, 27-30, 1503-1504.

Schmidt P. (2000): A képzés továbbképzés fontosságának szerepe a háziorvosi gyakorlatban. Egészségnevelés, 41, 5-6, 201.

Schmidt P. (2001a): A családorvosok képzésének országos modellje Győr-Moson-Sopron megyében. Orvosi Hetilap, 142, 1-4, 484.

Schmidt P. (2001b): Az egészségmegőrzés, egészségnevelés szerepe a háziorvosok és egészségügyi dolgozók képzésében, továbbképzésében. Egészségnevelés, 42, 4, 159-161.

Schmidt P. (2004a): A posztgraduális képzés egy modellje Alapellátási Szabadegyetem Győr-Moson-Sopron megyében. CSAKOSZ (Családorvosi Kutatók Országos Szövetsége) III. Nemzetközi Kongresszusa, Budapest, Előadás összefoglaló, 21-22.

Schmidt P. (2004b): Gazdaságossági kérdések szerepe az egészségügyi alapellátás reformjához kapcsolódóan: Gondolatok az Alapellátási Szabadegyetem 100. rendezvényén. Orvosi Hetilap, $145,18-22,355-357$.

Schmidt P. (2017): Az orvosképzés és -továbbképzés mint minőségi tudásmegosztás vizsgálata. Orvostovábbképzö Szemle (online), 2017. május 05. 18:00, http://otszonline.hu/egeszsegugyeink/ cikk/az_orvoskepzes_es_tovabbkepzes_mint_minosegi_tudasmegosztas_vizsgalata

Schmidt P. - Konczosné Szombathelyi M. (2017): Negyed évszázad a családorvosok képzésében és továbbképzésében: Alapellátási Szabadegyetem Győrött (1992-2017). Orvosi Hetilap, 158, 27, 1077-1079.

Schmidt P. - Konczosné Szombathelyi M. (2018a): A családorvoslás gyakorlati és speciális kérdései. A képzés, továbbképzés és tudásmegosztás szerepe az egészségügyi ellátásban: Alapellátási Szabadegyetem. Győr, 2017. szeptember 23. Orvosi Hetilap, 159, 8, 330-332.

Schmidt P. - Konczosné Szombathelyi M. (2018b): A tudásmegosztás szerepe az egészségügyi alapellátásban, különös tekintettel a családorvosok képzésére és továbbképzésére. Medicus Universalis, 51, 1, 42.

Schmidt P. - Menyhárt M. (2005): Körzeti orvosból háziorvos - a családok orvosának habitusváltozása az elmúlt 25 évben és a jövő kihivásai. VI: Sümegi Orvosi Napok, Előadás-összefoglaló, 15-18. 
Schmidt P. - Muzsay G. (2010): A gyermekorvosi ügyeleti ellátási rendszer korszerüsítése Győr városában; egy országos modell a prevenciós és szociálpediátriai munkában. In: CSAKOSZ IX. Kongresszusa: Program és összefoglalók. Pécs: 40-41.

Schmidt P. - Simon T. (1989): A körzeti orvoshoz fordulás motivációi - a betegek kérdöives felmérése. VEAB pályamunka, Várpalota-Györ

Schmidt P. - Végh K. (2003): Költség/haszon-elemzés és gazdasági kérdések szerepe az egészségügyi alapellátásban. Győr-Moson-Sopron Megyei Önkormányzat Kiadványa. Győr: Hazánk Kiadó Kft., 35-39.

Simai M. (2016): A harmadik évezred nyitánya. Budapest: Corvina Kiadó

Stavdal, A. (2016): Risk Embedded in Risk Intervention. The History of Prevention in Nordic Medicine. Családorvos Kutatók Országos Szervezete XV. kongresszusa, 2016. február 25-27. Budapest, Hotel Flamenco. Program és Összefoglalók. https://docplayer.hu/15993831-Csaladorvos-kutatok-orszagos-szervezete-xv-kongresszusa.html

Sveiby, K. E. (1997): The New Organizational Wealth: Managing and Measuring KnowledgeBased Assets. San Fransisco: Berrett-Koehler Publ., Inc.

Sveiby, K. E. (2001): Szervezetek új gazdagsága: a menedzselt tudás. Budapest: KJK-Kerszöv

Tomka J. (2005): A szakmai közösségek (Communities of Practice) hozzájárulása a szervezeti együttmüködés fejlesztéséhez. PhD-értekezés. Budapesti Műszaki és Gazdaságtudományi Egyetem, https://repozitorium.omikk.bme.hu/bitstream/handle/10890/425/ertekezes.pdf?sequence $=1$

\section{Online források}

KSH: Egészségügyi statisztikai évkönyv, 2016, http://www.ksh.hu/apps/shop.kiadvany?p_ kiadvany_id=992947\&p_temakor_kod=KSH\&p_lang $=\mathrm{HU}$

KSH: Tájékoztatási adatbázis, http://statinfo.ksh.hu/Statinfo/themeSelector.jsp?page=2\&szst= FEA

Állami Egészségügyi Ellátó Központ: Migrációs statisztikák, https://www.enkk.hu/hmr/index. $\mathrm{php} /$ migracios-statisztikak/eves-statisztikak

Egészségügyi Nyilvántartási és Képzési Központ: Beszámoló az egészségügyi ágazati humánerőforrás 2015. évi helyzetéről az egészségügyi ágazati humánerőforrás-monitoringrendszer alapján, 2016. https://www.enkk.hu/hmr/documents/beszamolok/HR_beszamolo_2015.pdf

URL1: http://www.jogiportal.hu/index.php?id=w3f4piojk8zv7syrm\&state=20000122\&menu= view

URL2: http://ofi.hu/erdekek-ertekek-tudasmegosztas

URL3: KSH: STADAT, https://www.ksh.hu/docs/hun/xstadat/xstadat_eves/i_fea002b.html 


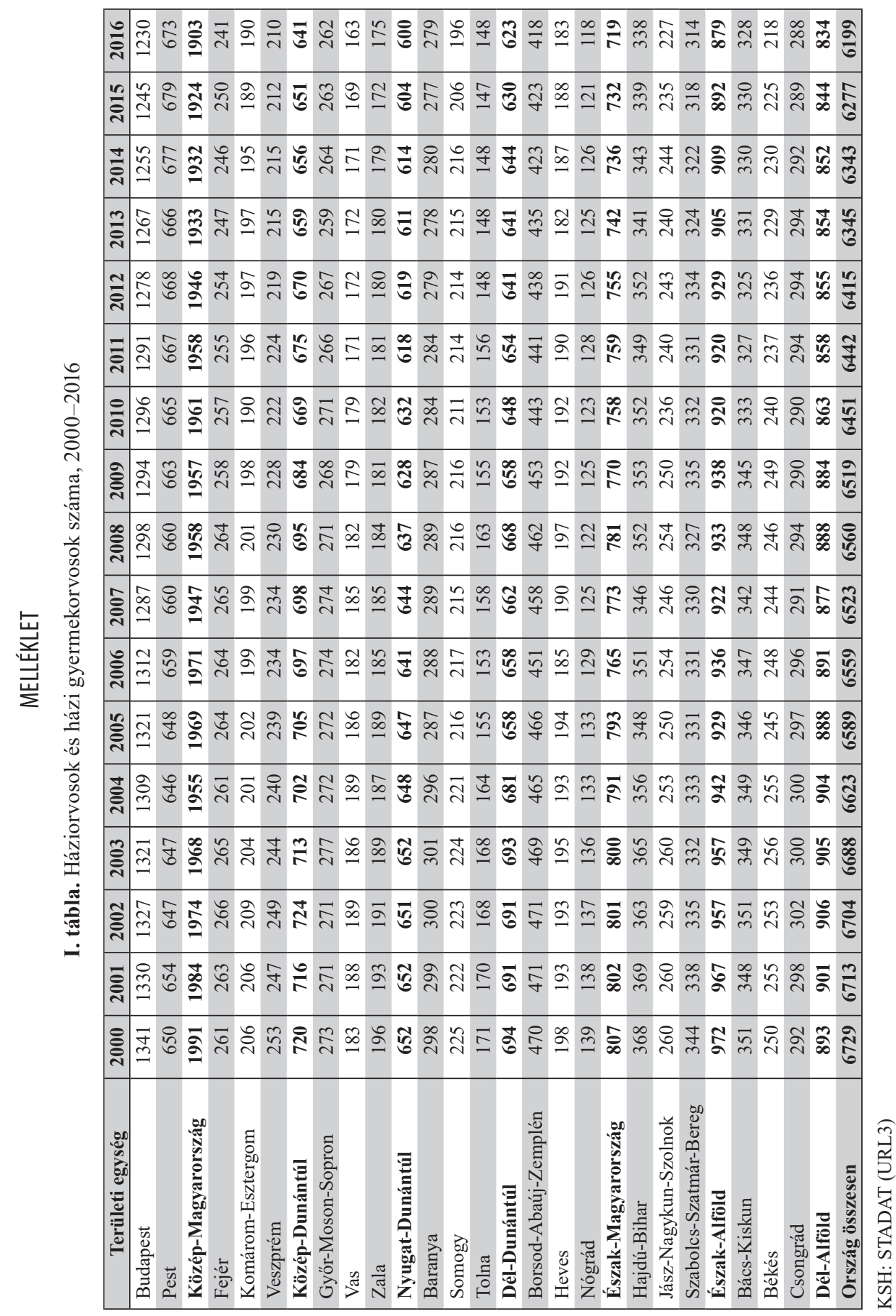




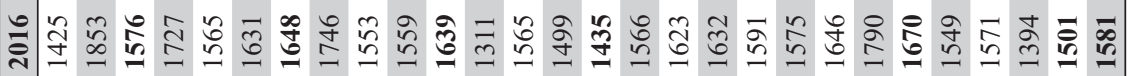

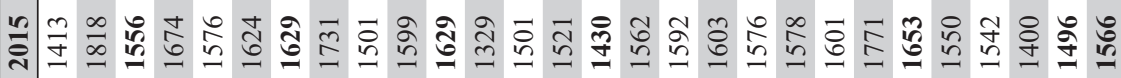

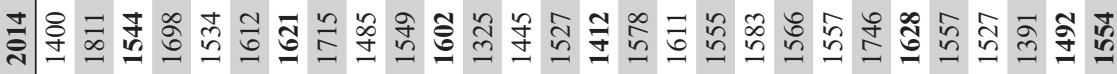

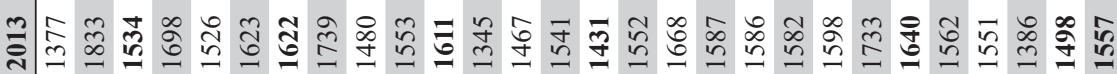

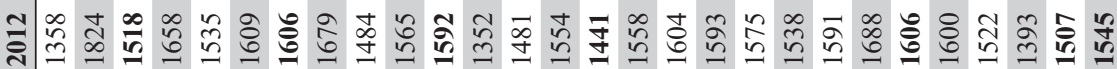

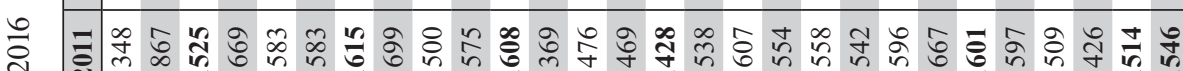

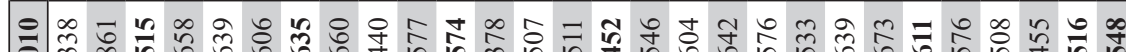

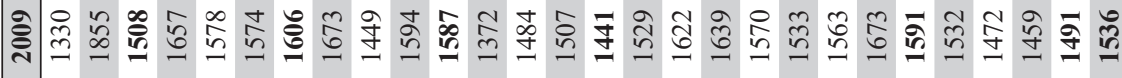

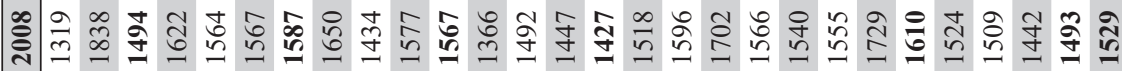

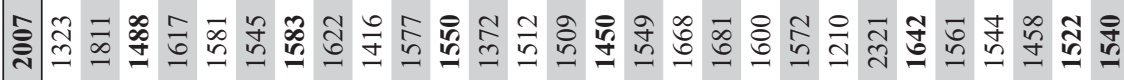

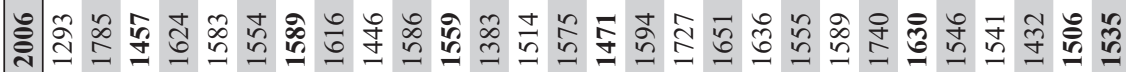

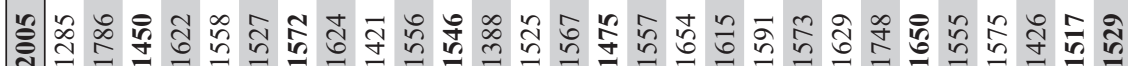

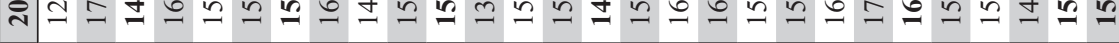

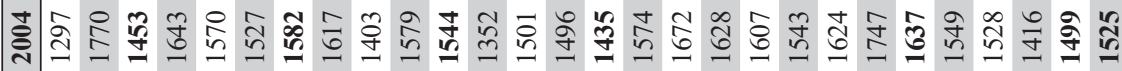

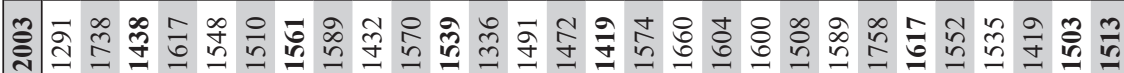

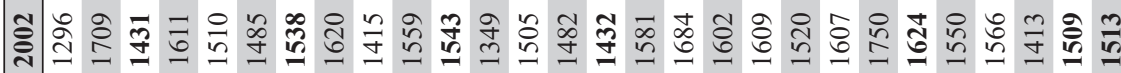

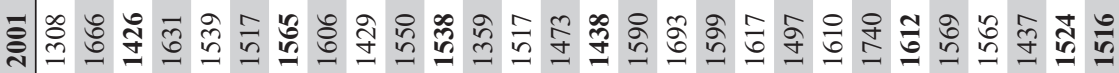

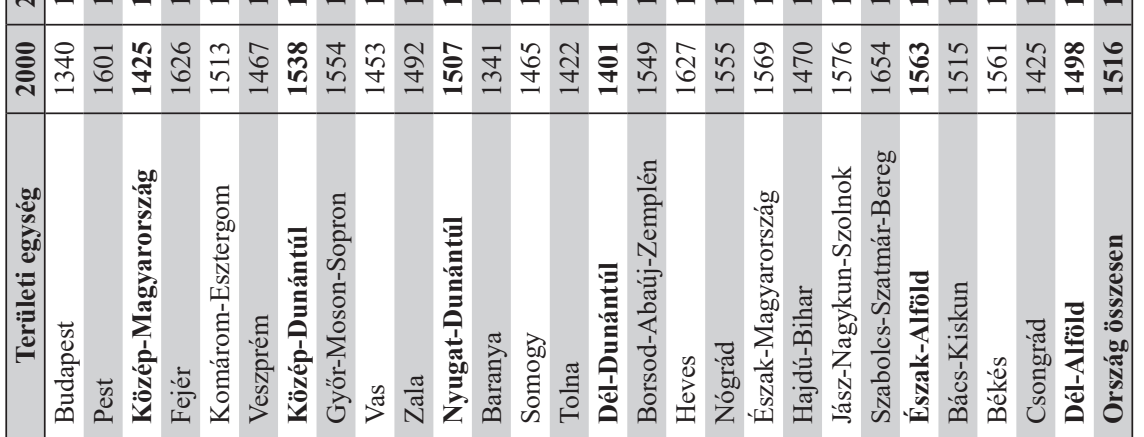

